Original Article

\title{
EFFECTIVITY OF 5\% DEXTROSE-DILUTED AND RINGER LACTATE- DILUTED PROPOFOL TO REDUCE INTRAVENOUS INJECTION PAIN IN PEDIATRIC PATIENT
}

\author{
Dian Raseka Parna ${ }^{1}$, Arie Utariani2a, Elizeus Hanindito ${ }^{2}$ \\ ${ }^{1}$ Resident of Department of Anesthesiology and Reanimation, Faculty of Medicine, Universitas Airlangga, Dr. Soetomo \\ Academic Hospital Surabaya \\ ${ }^{2}$ Consultant of Department of Anesthesiology and Reanimation, Faculty of Medicine, Universitas Airlangga, Dr. Soetomo \\ Academic Hospital Surabaya \\ a Corresponding Author: arieutariani1955@gmail.com
}

\begin{abstract}
Introduction: Propofol has been known as one out of many inductive drugs which, can cause pain during intravenous injection. There has been a high prevalence of injection pain in pediatric patients. The mechanism of injection pain has not been known. Some therapeutic methods have been tested to reduce the pain, with several success rates. Objective: To compare the effectivity of 5\% dextrose-diluted propofol and ringer lactate-diluted propofol, with dilution comparison of 1:1, in their role to reduce intravenous injection pain in pediatric patients, from age 2-15 years old during elective surgery in the Integrated Surgical Building Center of Dr. Soetomo General Hospital Surabaya. Method and Material: Forty-five patients PS ASA I-II, which fulfill inclusion criteria, were induced with general anesthesia. Patients had been selected randomly into three groups. Group I (control group) were injected with propofol without dilution. Group II was injected with propofol with a dilution of 5\% dextrose, into $5 \mathrm{mg} / \mathrm{ml}$ liquid. Group III was injected with propofol with a dilution of ringer lactate, into $5 \mathrm{mg} / \mathrm{ml}$ liquid. Result and Discussion: The level of pain was evaluated afterward, with responding to the four-point scale and spontaneous expression. Patients' blood pressure, mean arterial pressure, heart rate, and oxygen saturation were also examined after injection. Compared to the control group, those in groups with 5\% dextrose-diluted and ringer lactate-diluted propofol are not effective in reducing intravenous injection pain, with analytical statistics $\mathrm{p}=0.503$ ( $p>0.05$ ). Also, the dilution of propofol has no significant difference to the hemodynamic measurement of patients. Systolic and diastolic blood pressure, and mean arterial pressure were declined after the induction, but statistically insignificant. The heart rate of patients was inclined but also not significant. Conclusion: 5\% dextrose-diluted and ringer lactate-diluted propofol with a comparison of 1:1 were not significantly effective in reducing intravenous injection pain in pediatric patients.
\end{abstract}

Keywords: 5\% Dextrose; Ringer Lactate; Propofol Dilution; Injection Pain; Pediatric Pain.

\begin{abstract}
ABSTRAK
Pendahuluan: Propofol telah diketahui sebagai salah satu obat induksi yang sering menimbulkan nyeri saat penyuntikan. Insiden nyeri karena penyuntikan propofol secara intravena pada pasien anak sangat tinggi. Mekanisme nyeri pada saat penyuntikan propofol ini belum diketahui hingga saat ini. Berbagai teknik telah diupayakan untuk mengurangi kejadian nyeri tersebut, dengan angka keberhasilan yang berbeda-beda. Tujuan: Untuk membandingkan efektivitas dari propofol yang diencerkan dengan dextrose $5 \%$ dan ringer laktat dengan perbandingan pengenceran $1: 1$, dalam mengurangi nyeri injeksi intravena pada pasien pediatri, usia 2-15 tahun selama operasi elektif, di Gedung Pusat Bedah Terpadu, RSUD Dr. Soetomo Surabaya. Metode dan Bahan: Empat puluh lima pasien PS ASA I-II yang memenuhi kriteria inklusi, diinduksi dengan anestesi umum. Pasien yang telah dipilih secara acak dikelompokkan ke dalam tiga grup. Grup I adalah grup kontrol, yang diinjeksi intravena menggunakan induksi propofol. Grup II adalah grup yang diinjeksi intravena dengan propofol yang diencerkan dalam dextrose 5\% menjadi cairan dengan konsentrasi 5mg/ml. Grup III adalah grup yang diinjeksi intravena dengan propofol yang diencerkan dengan ringer laktat menjadi cairan dengan konsentrasi $5 \mathrm{mg} / \mathrm{ml}$. Hasil dan Pembahasan: Nyeri pada pasien setelah injeksi akan dievaluasi dengan skala empat titik dan ekspresi spontan dari pasien. Tekanan darah, MAP, denyut jantung, dan saturasi oksigen pada pasien akan dievaluasi setelah injeksi. Propofol yang diencerkan dengan dextrose 5\% dan ringer laktat tidak efektif dalam mengurangi
\end{abstract}


nyeri injeksi dibandingkan dengan kontrol, dengan $\mathrm{p}=0,503$ ( $\mathrm{p}>0,05)$. Hemodinamik pasien juga tidak mengalami perubahan secara signifikan. Rerata tekanan darah sistolik dan diastolik, dan MAP pasien menurun setelah injeksi, sedangkan denyut jantung dan saturasi oksigen pasien meningkat setelah injeksi. Kesimpulan: Propofol yang diencerkan dengan dextrose 5\% dan ringer laktat dengan perbandingan 1:1 tidak menurunkan nyeri injeksi intravena secara signifikan pada pasien pediatri.

Kata kunci: Dextrose 5\%; Ringer Laktat; Pengenceran Propofol; Nyeri.

Article info: Received 11 Dec 2019; Received in revised from 13 Jan 2020; Accepted 23 Jan 2020

\section{INTRODUCTION}

Propofol (or 2,6 diisopropyl phenol) first used in 1977, was diluted in chromofor, because of its hydrophobicity. ${ }^{1}$ Propofol was known as one of many induction drugs in anesthesiology. There are at least 15,506 patients using propofol for induction or sedation during elective operation in Dr. Soetomo General Hospital, Surabaya. ${ }^{2}$ Propofol often used because it has a quick onset, short duration of action, and low occurrence of adverse. ${ }^{1,3,4}$

However, propofol may induce pain during intravenous injection ${ }^{3}$, such as sharp pain, burnt-like pain, or excruciating pain. ${ }^{4}$ The incidence of pain during propofol intravenous injection is very high, from $28 \%$ to $90 \%$. $^{5}$ This made propofol injection pain is classified to seven highest clinical problems of modern anesthesiology. ${ }^{6}$ Yet, the mechanism of propofol injection pain has been unknown.

According to systematic review and meta-analysis in 2011, there are more than 60 methods used to reduce propofolinduced pain in adult patients, such as cooling, warming, injecting great veins, and using lidocaine, ketamine, opioid, metoclopramide, or thiopental before injections. ${ }^{7}$ In pediatric patients, there are at least 18 publications are made to reduce pain because of propofol injection. ${ }^{7} \mathrm{~A}$ research in Germany said propofol-induced pain can be reduced by diluting propofol from $0.5 \%$ to $10 \%$ for pediatric patients (age $2-6){ }^{8}$

Based on that early literature, this research about the effectivity of 5\%dextrose diluted propofol and ringer lactate diluted propofol to reduce intravenous injection pain in elective surgery in Dr. Soetomo General Hospital, Surabaya, was made.

\section{MATERIAL AND METHOD}

This research is an experimental study, a double-blind randomized-control-trial clinical research, to compare the effectivity of 5\%-dextrose diluted and ringer lactate diluted propofol to reduce intravenous injection pain during induction in elective surgery.

The population of this research is pediatric patients undergoing elective surgery in the Center of Integrated Surgery Building, Dr. Soetomo General Hospital.



Figure 1. The Formula of Sampling Calculation

The inclusion criteria are pediatric patients with age of 2-15 undergoing elective surgery with general anesthesia, 
categorized into American Society of Anesthesiologist (ASA) classification stage I-II according to the clinical status of patients, were under venous infusion at the dorsal part of the hand, and not having any phlebitis.

From these criteria, there are 45 patients included being the subject of this research, classified into three groups: one control group (with non-diluted propofol), one with 5\%-dextrose diluted propofol, and one with ringer lactate diluted propofol. The intravenous injection pain was using a 4point extremities movement scale and spontaneous expression scale. Vital signs of patients was also examined.

The data of this study were analyzed with Statistical Product and Service (SPSS) version 10 for Windows. The data with normal distribution were statistically analyzed with ANOVA test, and Multiple Comparisons LSD and others were analyzed Kruskal Walls non-parametric statistic test. It is stated to be significant if $\mathrm{p}<0.05$.

\section{RESULT AND DISCUSSION}

The minimum sample needed for each group of this study is 14.2 and concluded into 15 patients. The total sample would be 45 patients and categorized into three groups, group I, II, and III. The group I will be injected with propofol without dilution, group II will be injected with D5\% diluted propofol, and group III will be injected with ringer lactate diluted propofol.

Table 1 shows the demographic distribution of patients, including sex, age, body weight, and PS ASA. The value of homogeneity test was the data were homogenous and normal in distribution.
Table 1. Demographic characteristics of patients

\begin{tabular}{|c|c|c|c|c|}
\hline Variables & $\begin{array}{c}\text { Propofol } \\
\text { Without } \\
\text { Dilution } \\
(n=15)\end{array}$ & $\begin{array}{c}\text { D5\% } \\
\text { Diluted } \\
(n=15)\end{array}$ & $\begin{array}{c}\text { Ringer } \\
\text { Lactate } \\
\text { Diluted } \\
(\mathbf{n}=15)\end{array}$ & P-Value \\
\hline \multicolumn{5}{|l|}{ Sex } \\
\hline Male & $\begin{array}{c}8 \\
(53.3 \%)\end{array}$ & $\begin{array}{c}9 \\
(60 \%)\end{array}$ & $12(80 \%)$ & $0.283^{* *}$ \\
\hline Female & $\begin{array}{c}7 \\
(46.7 \%)\end{array}$ & $\begin{array}{c}6 \\
(40 \%)\end{array}$ & $\begin{array}{c}3 \\
(20 \%)\end{array}$ & \\
\hline Age & $10.5 \pm 4.0$ & $8.3 \pm 4.9$ & $9.4 \pm 4.3$ & $0.409 * *$ \\
\hline $\begin{array}{l}\text { Body } \\
\text { Weight } \\
\text { PS ASA }\end{array}$ & $36.9 \pm 18.1$ & $25.3 \pm 14.4$ & $29.8 \pm 14.5$ & $0.143 * *$ \\
\hline 1 & $\begin{array}{c}6 \\
(40 \%)\end{array}$ & $2(13.3 \%)$ & $5(33.3 \%)$ & $0.245^{* *}$ \\
\hline 2 & $\begin{array}{c}9 \\
(60 \%) \\
\end{array}$ & $\begin{array}{c}13 \\
(86.7 \%) \\
\end{array}$ & $\begin{array}{c}10 \\
(66.7 \%) \\
\end{array}$ & $0.283^{* *}$ \\
\hline
\end{tabular}

The group I as the control group, those who were injected by propofol without dilution. This group consists of 8 males and 7 females, aged 4-15 with mean 10.5, (SD $=4.0)$, mean body weight $36.9(\mathrm{SD}=18.1)$ $\mathrm{kg}$, and PS ASA 1 is 6 , and PS ASA 2 is 9. Group II was injected with D5\% diluted propofol, consists of nine males and five females, age 2-15 with mean of 8.3 (SD = 4.9), mean body weight $25.3(\mathrm{SD}=14.4)$ $\mathrm{kg}$, and PS ASA 1 is two, and PS ASA 2 is thirteen. Group III was injected with ringer lactate diluted propofol, consists of 12 male and three female, age 2-15 with mean of 9.4 (SD = 4.3), mean body weight 29.8 (SD $=14.5) \mathrm{kg}$, and PS ASA 1 is five, and PS ASA 2 is ten. Three groups are compared because there is no significant difference of the data in sex, age, body weight, and PS ASA. The data was homogenous so that variables are not continued to another statistical analysis.

A recent study stated that propofol dilution with D5\% in 100 patients shows $32 \%$ of patients in the control group have severe pain, whether only $10 \%$ of patients in $\mathrm{D} 5 \%$ group have severe pain. ${ }^{9}$ 
Table 2. Normality Test of Research Variables

\begin{tabular}{|c|c|c|c|}
\hline Variables & $\begin{array}{l}\text { Propofol } \\
\text { without } \\
\text { dilution } \\
\text { (P-Value) }\end{array}$ & $\begin{array}{c}\text { D5\% } \\
\text { diluted } \\
\text { propofol } \\
\text { (P-Value) }\end{array}$ & $\begin{array}{c}\text { Ringer } \\
\text { lactate } \\
\text { diluted } \\
\text { propofol } \\
\text { (P-Value) }\end{array}$ \\
\hline Age & $\begin{array}{c}10.5 \pm 4.0 \\
(0.561)\end{array}$ & $\begin{array}{l}8.3 \pm 4.9 \\
(0.368)\end{array}$ & $\begin{array}{l}9.4 \pm 4.3 \\
(0.990)\end{array}$ \\
\hline Bodyweight & $\begin{array}{c}36.9 \pm 18.1 \\
(0.604)\end{array}$ & $\begin{array}{c}25.3 \pm 14.4 \\
(0.654)\end{array}$ & $\begin{array}{c}29.8 \pm 14.5 \\
(0.584)\end{array}$ \\
\hline Pain scale & $\begin{array}{l}4.7 \pm 1.3 \\
(0.700)\end{array}$ & $\begin{array}{l}4.9 \pm 1.1 \\
(0.499)\end{array}$ & $\begin{array}{l}4.3 \pm 1.9 \\
(0.855)\end{array}$ \\
\hline \multicolumn{4}{|c|}{ Hemodynamic before treatment } \\
\hline Systolic BP & $\begin{array}{c}110.6 \pm 12.4 \\
(0.677)\end{array}$ & $\begin{array}{c}106.7 \pm 17.6 \\
(0.699)\end{array}$ & $\begin{array}{c}105.3 \pm 11.4 \\
(0.971)\end{array}$ \\
\hline $\begin{array}{l}\text { Diastolic } \\
\text { BP }\end{array}$ & $\begin{array}{c}70.1 \pm 11.3 \\
(0.515)\end{array}$ & $\begin{array}{c}63.1 \pm 12.9 \\
(0.718)\end{array}$ & $\begin{array}{c}62.1 \pm 11.1 \\
(0.960)\end{array}$ \\
\hline MAP & $\begin{array}{c}83.6 \pm 10.9 \\
(0.897)\end{array}$ & $\begin{array}{c}77.7 \pm 14.0 \\
(0.694)\end{array}$ & $\begin{array}{c}76.5 \pm 10.5 \\
(0.987)\end{array}$ \\
\hline Heart rate & $\begin{array}{c}97,8 \pm 17,5 \\
(0,771)\end{array}$ & $\begin{array}{c}110 \pm 21,5 \\
(0,976)\end{array}$ & $\begin{array}{c}97.7 \pm 14.6 \\
(0.532)\end{array}$ \\
\hline $\mathrm{SpO2}$ & $\begin{array}{c}99.1 \pm 0.6 \\
(0.057) \\
\end{array}$ & $\begin{array}{l}98.8 \pm 0.4 \\
\left(0.002^{*}\right) \\
\end{array}$ & $\begin{array}{l}99.1 \pm 0.4 \\
(0.001 *)\end{array}$ \\
\hline \multicolumn{4}{|c|}{ Hemodynamic after treatment } \\
\hline Systolic BP & $\begin{array}{c}102.5 \pm 14.8 \\
(0.803)\end{array}$ & $\begin{array}{c}103.7 \pm 13.2 \\
(0.978)\end{array}$ & $\begin{array}{c}101.5 \pm 16.4 \\
(0.862)\end{array}$ \\
\hline $\begin{array}{l}\text { Diastolic } \\
\text { BP }\end{array}$ & $\begin{array}{c}61.9 \pm 11.2 \\
(0.919)\end{array}$ & $\begin{array}{c}63.1 \pm 11.5 \\
(0.935)\end{array}$ & $\begin{array}{c}62.7 \pm 16.7 \\
(0.977)\end{array}$ \\
\hline MAP & $\begin{array}{c}75.4 \pm 11.5 \\
(0.978)\end{array}$ & $\begin{array}{c}76.6 \pm 10.6 \\
(0,688)\end{array}$ & $\begin{array}{c}75.7 \pm 15.7 \\
(0.976)\end{array}$ \\
\hline Heart rate & $\begin{array}{c}107.4 \pm 19.1 \\
(0.457)\end{array}$ & $\begin{array}{c}112,5 \pm 23,8 \\
(0,920)\end{array}$ & $\begin{array}{c}104.7 \pm 19.9 \\
(0.727)\end{array}$ \\
\hline $\mathrm{SpO2}$ & $\begin{array}{c}99.2 \pm 0.4 \\
(0.002 *)\end{array}$ & $\begin{array}{c}98,8 \pm 0,414 \\
(0.002 *)\end{array}$ & $\begin{array}{c}99.1 \pm 0.3 \\
\left(0.0000^{*}\right) \\
\end{array}$ \\
\hline
\end{tabular}

Numeric normality test is conducted to test the data. P-value from the variable is taken and tested using one-sample Kolmogorov-Smirnov. Data is normally distributed if the value of $P>0.05$. Oxygen saturation of these samples, on the other hand, shows a significant difference.

Table 3 showed that without data analysis using a statistical method, it is found that group III responses show slight differences to other groups, in no pain and mild pain. Still, for severe pain, group III also shows more patients than other groups. According to the t-test between three groups, it is found that the p-value is 0,503 $(p>0.05)$, which means there is no significant difference between groups.

Table 3. Pain Response to Propofol Injection

\begin{tabular}{|c|c|c|c|c|}
\hline \multirow[b]{2}{*}{$\begin{array}{l}\text { Pain score } \\
\text { (The } \\
\text { FLACC } \\
\text { pain score) }\end{array}$} & \multicolumn{3}{|c|}{ Group } & \multirow[b]{2}{*}{$\begin{array}{c}\text { P- } \\
\text { Value }\end{array}$} \\
\hline & $\begin{array}{c}\text { I } \\
\text { Propofol } \\
\text { without } \\
\text { dilution }\end{array}$ & $\begin{array}{c}\text { II } \\
\text { D5\% } \\
\text { diluted- } \\
\text { propofol }\end{array}$ & $\begin{array}{l}\text { III } \\
\text { Ringer } \\
\text { lactate } \\
\text { diluted } \\
\text { propofol }\end{array}$ & \\
\hline No pain (2) & $1(6.7 \%)$ & 0 & $3(20 \%)$ & \multirow{4}{*}{$0.503 *$} \\
\hline $\begin{array}{l}\text { Mild pain } \\
(3-4)\end{array}$ & $5(33.3 \%)$ & $5(33.3 \%)$ & $6(40.0 \%)$ & \\
\hline $\begin{array}{l}\text { Moderate } \\
\text { pain (5-6) }\end{array}$ & $8(53.3 \%)$ & $9(60 \%)$ & $4(26.7 \%)$ & \\
\hline $\begin{array}{l}\text { Severe pain } \\
(7-8)\end{array}$ & $1(6.7 \%)$ & $1(6.7 \%)$ & $2(13.3 \%)$ & \\
\hline
\end{tabular}

The statistic analysis stated that the whole of the research samples was not effectively significant to reduce the propofol pain. Many things can affect the final result of this research. The sample of pediatric patients were difficult to evaluate. When the children was far from the parent would make the children feel anxious, the solution was they would give midazolam intravenous medicine to reduce their anxiety.

Patients' age also affects the result of this study. Since age 2-15 is classified into pediatrics group age, the immaturity of the psychological aspect, response to a new environment, and adaptional ability have a great role in their responses to pain. Separation anxiety in pediatric patients may also affect pain reactions in pediatric patients. ${ }^{8,10}$ 
Table 4. Hemodynamic Changes between Groups

\begin{tabular}{|c|c|c|c|c|c|}
\hline \multicolumn{2}{|c|}{ Group } & \multirow{2}{*}{$\frac{\text { Pre }}{110.0 \pm 12.4}$} & \multirow{2}{*}{$\begin{array}{c}\text { Post } \\
102 \pm 14.8\end{array}$} & \multirow{2}{*}{$\begin{array}{c}\text { Delta } \\
-8.1 \pm 12.1\end{array}$} & \multirow{2}{*}{$\frac{\text { P-value }}{0.021^{* *}}$} \\
\hline & I & & & & \\
\hline \multirow[t]{3}{*}{ SBP } & II & $106.7 \pm 17.6$ & $103.7 \pm 13.2$ & $-3.1 \pm 12.1$ & 0.342 \\
\hline & III & $105.3 \pm 11.4$ & $101.5 \pm 16.4$ & $-3.8 \pm 16.2$ & 0.379 \\
\hline & I & $70.1 \pm 11.3$ & $61.9 \pm 11.2$ & $-8.2 \pm 10$ & $0.007 * *$ \\
\hline \multirow[t]{3}{*}{ DBP } & II & $63.1 \pm 12.9$ & $63.1 \pm 11.5$ & $-0.07 \pm 10.5$ & 0.981 \\
\hline & III & $62.1 \pm 11.1$ & $62.7 \pm 16.7$ & $0.6 \pm 15$ & 0.879 \\
\hline & I & $83.6 \pm 10.9$ & $75.4 \pm 11.5$ & $-8.2 \pm 9.7$ & $0.006^{* *}$ \\
\hline \multirow[t]{3}{*}{ MAP } & II & $77.7 \pm 14.0$ & $76.6 \pm 10.6$ & $-1.0 \pm 9.7$ & 0.677 \\
\hline & III & $76.5 \pm 10.5$ & $75.6 \pm 15.7$ & $-0.9 \pm 14.5$ & 0.820 \\
\hline & I & $97.8 \pm 17.5$ & $107.4 \pm 19.1$ & $9.6 \pm 12.4$ & $0.009 * *$ \\
\hline \multirow[t]{3}{*}{ HR } & II & $110 \pm 21.5$ & $112.5 \pm 23.8$ & $2.5 \pm 16.5$ & 0.572 \\
\hline & III & $97.7 \pm 14.7$ & $104.7 \pm 20$ & $7.1 \pm 22.8$ & 0.251 \\
\hline & I & $99.0 \pm 0.6$ & $99.2 \pm 0.4$ & $0.13 \pm 0.4$ & 0.157 \\
\hline \multirow[t]{2}{*}{ SpO2 } & II & $98.8 \pm 0.4$ & $98.8 \pm 0.4$ & 0 & 1 \\
\hline & III & $99.1 \pm 0.4$ & $99.1 \pm 0.3$ & $-0.07 \pm 0.3$ & 0.317 \\
\hline
\end{tabular}

$* * \mathrm{p}<0.05$, t-test statistical test shows significant difference

Table 4 showed that in Group I, the hemodynamic change is shown in group I (Blood pressure declines). This can be caused by the drastic change of peripheral resistance in systemic blood vessels by inhibition of sympathetic vasoconstriction, heart contractility, and preload. However, in group II and III, the change is insignificant. This phenomenon can be explained by the steady concentration of propofol in blood takes longer time than in the control group, since the propofol is diluted in another solution. ${ }^{11}$

\section{CONCLUSION}

The use of 5\%-dextrose diluted propofol and ringer lactate diluted propofol with the comparison of 1:1 are not effective to reduce intravenous injection pain in pediatric patients and are not significant to affect patients' hemodynamic.

\section{REFERENCES}

1. Soenarto, Ratna F, Chandra S. Buku Ajar Anestesiologi. Departemen Anestesiologi dan Intensive Care Fakultas Kedokteran Universitas Indonesia / RS Cipto Mangunkusumo. Jakarta. 2012;

2. Rekapitulasi Pasien Operasi Elektif Gedung Bedah Pusat Terpadu. Surabaya: Departemen Anestesiologi dan Reanimasi Fakultas Kedokteran Universitas Airlangga / RSUD Dr Soetomo Surabaya. 2013-2014;

3. Stoelting RK and Hiller SC. Pharmacology \& Physiology in Anesthetic Practice 4th Edition. Philadelphia. 2006;

4. Liljeroth, Elisabeth. Pain Induced by Propofol - Clinical Studies on Drug Composition and Administration. Department of Anesthesiology and Intensive Care, Malmo University Hospital, Lund University. Malmo. 2007;

5. Klement W, Arndt JO. Pain on Injection of Propofol: Effects of Concentration and Diluent. $\mathrm{Br} \mathrm{J}$ Anaesth. 1991; 67: 281-284.

6. Macario A, Weinger $\mathrm{M}$, Truong $\mathrm{P}$ and Lee M. Which Clinical Anesthesia Outcomes are Both Common and Important to Avoid? The Perspective of a Panel of Expert Anesthesiologist. Anesth Analg. 1999; 88:1085-1091.

7. Jalota, Leena et al. Prevention of Pain on Injection of Propofol: Systematic Review and Meta-analysis. BMJ 2011; 342: d1110. 
8. Soltesz S, Silomon M, Graf G, Mencke T, Boulaadass S, Molter GP. Effect of 0,5\% Dilution of Propofol on Pain on Injection During Induction of Anesthesia in Children. Anesthesiology. 2007; 106: 80-84.

9. Yamakage M, Iwasaki S, Satoh JI and Namiki A. Changes in Concentrations of Free Propofol by Modification of the Solution. Anesth Analg. 2005; 101:385-388.

10. Butterworth JF, Mackey DC, Wasnick JD. Morgan \& Mikhail's Clinical Anesthesiology 5th Edition. East Norwalk: Appleton \& Lange. 2013;

William EL, Hildebrand KL, McCormick SA, Bedel MJ. The effect of intravenous lactated Ringer's solution versus $0,9 \%$ sodium chloride solution on serum osmolality in human volunteers. Anesth. Analg. 1999; 88 (5): 999-100 